\title{
Using Theory of Learning and Awareness to Bring About Learning Through a School-based Environmental Field Project
}

\author{
Tammy Kwan \\ Faculty of Education, The University of Hong Kong, Pokfulam Road, \\ Hong Kong \\ Eva Chan \\ The Hong Kong Chinese Christian Churches Union Logos Academy, \\ Phase 1 \& 3, Area 73A, Tseung Kwan O, Hong Kong
}

A school-based environmental field project 'What Happens Around You and Your School Area?' was designed under the School-based Curriculum Project Scheme (2001-2002) supported by the Hong Kong Education Manpower Bureau (formerly the Education Department). This school-based environmental field project, with heavy inclusion of environmental elements, was designed in the form of issue-based field inquiry based on student-centred learning to encourage subsequent meaningful learning activities such as group discussion, role-playing exercises and photograph exhibition in class. The field project possesses distinctive geographical and environmental characteristics of the school surrounding environments to bring about meaningful learning among students who study in a local standard new town secondary school in Hong Kong. This paper aims to share this field project experience of designing meaningful issue-based field inquiry using the theory of learning and awareness (Marton \& Booth, 1997) to open up the space of learning for students (Marton et al., 2004; Runesson \& Marton, 2002). Also based on the framework of educational and environmental ideologies (Fien, 1993), the intended learning outcomes of the field project are to empower students to become active small environmentalists (Kwan, 1995) who are well prepared in terms of geographical and environmental knowledge, skills and values.

Keywords: school- and issue-based inquiry field project, theory of learning and awareness, space of learning, educational and environmental ideologies

\section{Introduction}

During the last decades of the 20th Century, there was a change from seeing education as a process of transformation to seeing it as a process which actively involves learners in 'certain ways of seeing or experiencing something through which the world is perceived' (Marton et al., 2004: 8). Quality learning, which is more student-centred and involves a much higher level of cognitive construction of knowledge, is no longer a simple function of the individual characteristics of a learner, the quantity of subject knowledge acquired by the students and the pedagogies adopted by teachers (Ramsden, 1988). This trend of bringing about genuine student learning had not been explicitly conveyed and advocated in 
the Hong Kong school education until the curriculum reform document Learning to Learn: The Way Forward in Curriculum Development was published (CDC, 2000a).

The messages of moving towards student-centred learning, designing a learner-focused approach curriculum, enabling life-long and life-wide learning, reducing knowledge transmission and emphasising meaningful learning experiences are stressed and made clear to all stakeholders in the reform document (CDC, 2000a: 7, 15, 17, 21). In line with the overall aims and goals of the future education and school curriculum, another document (CDC, 2000b) on the key learning area (KLA) of personal, social and humanities education (PSHE) was published to further emphasise its learner-focused orientation. This KLA aims to enable students 'to understand themselves, society and the world at large; to maintain a healthy personal development; and to contribute to the well being of the family, the local community, the nation and the world as confident, informed and responsible persons' (CDC, 2000b: 5, 11, 22). Among the six strands proposed in PSHE, two of them, namely 'personal and social development' and 'social systems and citizenship' offer clear messages of enhancing environmental education in the new school curriculum framework. A strongly built-in dimension of environmentally concerned values and attitudes is also brought about through the 'development of the core and sustaining values and attitudes of the society' among students so as to allow them to 'clarify their values and make decisions concerning the various personal and social issues' through the enquiry process (CDC, 2000b: 16). These aims and targets of education and curriculum development have become the underlying rationale in designing this environmental field project entitled 'What Happens Around You and Your School Area?' (see Appendix for full details of the field project design).

With such background and information in mind, the prime concerns when designing this field project were its appropriateness and effectiveness in helping to realise those aims and targets specified in the curriculum reform documents and in the light of enhancing environmental and geographical education among students. This field project was designed to enable students to learn through, and engage in, activities designed to critically explore and understand their familiar school surroundings which represent a widened, open learning context and an authentic environment with variation. This is to seek a breakthrough to the limitations posed by the four walls of the classroom and to maximise and open up students' learning experiences. This indeed echoes the call of the educational reform by injecting life-wide learning for students and the emphasis of providing students with sufficient learning experiences. To help students to acquire direct and first-hand information in the field through practising various field-study skills, this field project also reflects the demand for developing students with various generic skills (CDC, 2000b: 16, 39-59). Furthermore, the arousal of students' awareness of their immediate surroundings through this field project becomes the first step for students to understand themselves better, which then extends to the society and the world at large. The expectations upon the students are to contribute at least to the well-being of their local community, which are all advocated targets for enhancing environmental education specified in the reform documents. The nurturing of students to establish values and attitudes with commitment and responsibility to sustainable environmental 
behaviour, and the ability to make judgements and decisions between dilemmas, are essentially the focal emphasis of the educational and environmental educational ideologies (Fien, 1993: 20-1, 27).

The purpose of this paper, therefore, is to share the design of an environmental field project by analysing how environmental and geographical learning of the surrounding school environment can be brought about. This paper contains three parts. The first part focuses on the discussion of the different types of learning environments and task activities structured in this field project. Using Marton and Booth's (1997) theory of learning and awareness, students' learning experience is opened up through the provision of different dimensions of variations (Marton et al., 2004; Runesson \& Marton, 2002). By so doing, it is hoped to portray the opening up of greater environmental and geographical learning space to enable students to become capable and active self-directed small environmentalists (Kwan, 1995). Using the ideas conveyed by Fien (1993) in discussing the ideologies of both education and environmental education, the second part of this paper focuses on justifying the teaching and learning approaches this field project adopted to realise the aims and objectives as embraced by the ideologies specified above. The third part of the paper contains an analytical discussion of the intended learning outcomes on the nature of the activities included in this field project with respect to knowledge, skills, values and attitudes advocated in achieving effective and successful geographical and environmental education.

\section{Using Theory of Learning and Awareness to Open Up the Space of Learning Through Variation to Bring About Effective and Meaningful Environmental and Geographical Learning}

To equip students with the ability to learn how to learn and to free students from a rigid curriculum framework are the two central aims in the Hong Kong educational reform. This openness of learning is also critical to determine the success and effectiveness of bringing about meaningful environmental and geographical education among students. To achieve them, widening students' space of learning and equipping them with the strategies to construct knowledge seem to be the most critical and essential steps (CDC, 2000a: 53, 21). Before examining the use of different learning activities designed in this field project, let us first make a brief examination of the nature of the theory of learning and awareness which is used as a theoretical framework to open up the space of students' learning through variation.

The theory of learning and awareness is put forward by Marton and Booth (1997) to examine why some teaching was more effective than others in inducing meaningful learning outcomes. This theory emerges as an approach to studying learning outcomes from the viewpoint of varying students' experiences to help them to be aware of and able to discern all the critical features that we want them to learn. This requires the students to experience variation of these critical features. The students can achieve better quality of learning if they can discern these features simultaneously so that the part-whole relationship becomes clear. To do so successfully, we are in fact opening up the learning space of the students 
through enacting the objects of learning that are intended by the teachers by means of variation (Marton et al., 2004; Runesson \& Marton, 2002).

Being aware of the qualitatively different ways in which students see or learn an object, and through careful reflection and comparison with the teacher's ways of seeing or teaching that object, the students come to a focal awareness of different aspects (dimensions of variation) of the object and so are able to discern more critical features of that object simultaneously. As a result, the students are able to reach a deeper understanding of such an object of learning. However, the effectiveness of a given teaching method or approach depends very much on such a method or approach being able to allow the students to discern the critical features of the object of learning and come to a better understanding of what has to be learned.

The theoretical concepts of discernment, simultaneity and variation described above are grounded in the empirical research of learning and awareness (Marton \& Booth, 1997) and further elaborated into the space of learning and variation (Marton et al., 2004; Runesson \& Marton, 2002). Granted the assumption that these are highly significant in relation to certain outcomes of learning, it would make sense to look at teaching from the same point of view. This implies that the same theoretical concepts are used when analysing learning as well as teaching. According to Marton and Booth (1997), certain patterns of variation characterise certain ways of experiencing a phenomenon. In order to bring about a particular way of experiencing a particular phenomenon, it is necessary to follow that very pattern of variation. The object of study is thus to explore the extent to which teachers are contributing to constituting such a pattern of variation. Unless variation is created, students cannot discern the learning content and will thus be at a disadvantage in developing their awareness towards the specific content they are exposed to. Such variation is particularly critical in creating intellectual challenges among students (Marton \& Booth, 1997). With variations, students can see differences and similarities. This certainly helps discernment and raises awareness. At the same time, those aspects of the learning object that are discerned and held simultaneously should be organised in distinctive focal awareness with regard to a particular critical feature (Marton et al., 2004). With these ideas in mind, the structural design of this field project and its way of using variation to bring about focal awareness is described in the next section to illustrate and verify its success in bringing about effective and meaningful geographical and environmental intended learning among students.

\section{Overview of the tasks included in the field project}

This field project required students to walk along a trail, which constituted four field sites beginning from the school garden to areas near to the school. The school is located in a new town situated in the northwestern part of the New Territories of Hong Kong. It took the students about two and a half hours to complete this trail and the associated activities that were designed for them at each of the four sites. To begin with, it has to be stated clearly what activities constituted this field project in sequence. The structural procedures of the activities and their teaching and learning targets are summarised below (see Appendix for full details of the field project). 
(1) Teachers designed this field project by exposing students to four different aspects of the environment surrounding the school campus and its nearby area. Accordingly, this variation of studying different environments forms the critical feature of the field project.

(2) Students formed into groups of five to collect data and to complete the tasks assigned to the four field sites to explore:

(a) the natural environment (to study vegetation and its conservation in the school garden);

(b) the urban environment (to associate urban expansion and degradation of the living environment with the construction of the West Rail - a new transportation line linking the northwestern part the New Territories (including Yuen Long new town) to the urban area of Hong Kong);

(c) the industrial environment (to investigate the pollution problem with the existence of manufacturing activities nearby); and

(d) the rural environment (to correlate the degradation of rural environment with the process of urban encroachment as it appears in (b) and (c) above).

(3) Students engaged in different subsequent classroom activities to further explore and understand the four environments from other perspectives by completing the follow-up tasks in the worksheet. They were:

(a) to work with other group members to search for related information from the Internet;

(b) to organise the data collected from various field sites which represent different environments;

(c) to discuss the issues and dilemmas as raised in the worksheet and identified from the field sites;

(d) to communicate and negotiate with group members to come up with decisions on those think-in-depth questions; and

(e) to present the discussion results.

(4) Students in each group selected one self-composed photograph to show the best and the worst scene when they walked along the trail to complete the field project.

(5) Students exhibited their selected photographs on the bulletin board to share with the other schoolmates their feelings about the school and the nearby different environments that they had explored.

The activities that the students engaged in were characterised by their great diversity and wide range of purposes. This is to prepare students with meaningful learning and awareness of the critical features through widening the learning space among them, which is very much encouraged by the Hong Kong educational reform (CDC, 2000a: 53).

\section{Variation in opening up space of learning in the field}

When analysing this field project with regard to the objects of learning, it is apparent that the strategies of learning to explore and understand the school environment are in focus. It has to be stressed that the strategies used are the most essential elements to prepare students to achieve the prime target of the Hong 
Kong educational reform, that is, to learn how to learn (CDC, 2000a). It is also the prerequisite of nurturing students to become small environmentalists (Kwan, 1995). The strategies of learning of this field project involve making up three aspects of variation which open up the learning space for students to achieve the object of learning, that is, to develop environmental awareness through better understanding of the school surroundings. They are (1) variation in the types of environment to be studied, (2) variation in students' learning activities and their interaction, and (3) variation in the level of the learning tasks to develop environmental awareness. In short, the space of learning is characterised in terms of what aspects of the learning object are focused upon, what variations are opened to form a space of variation (Runesson \& Marton, 2002: 36).

\section{Variation in the types of environment to be studied}

Geography is concerned with the contrasting patterns of people-environment relationships and contrasting patterns of human use of the earth (Fien et al., 1989). So, to be aware of the aspects that constitute the environment as a whole will help students to identify how the environmental patterns contrast with each other. Or, the other way round, students can build up an overview of the whole environment by comparing and then merging these contrasting patterns of human use of the environment. This field project adopted the latter approach. By providing students with the opportunity to investigate the four different surrounding environments of the school, namely, the natural environment (i.e. the vegetation 'ecosystem' in the school garden), the urban environment (i.e. the urban development of Yuen Long New Town), the industrial environment (i.e. the polluting environment of a nearby industrial estate), and the rural environment (i.e. the degraded rural landscape brought about by urban encroachment), the possible aspects of environment that students have to pay attention to in other related field studies could make sense to them. This forms the basic strategy for students to explore, discern and understand the various environments. It is also hoped to engage students to acquire the necessary skills to study other different environments but with a similar nature to this field project in the future.

\section{Variation in students' learning activities and their interactions}

As mentioned earlier, a good way to bring about genuine learning is to widen the space of learning among students. Undoubtedly, this has to be achieved by providing diversified learning or teaching approaches, strategies and resources (CDC, 2000a: 53). As we have seen, the diversified learning activities provided in this field project maximise the degree of interactions among students and among field sites through the provision of different learning activities in terms of:

- group investigation in the four field sites representing the different environments;

- group investigation through searching information from the Internet, organising data collected;

- group investigation by exchanging ideas, communicating and negotiating with each other during discussion; 
- group preparation for the role-play activity based on their attitudes towards the four different environments;

- group presentation of the discussion results to the whole class;

- receiving feedback from both teacher and other group members;

- role playing which involves interactions among groups; and

- group presentation of their own reflection to the whole school through holding a photograph exhibition.

It is worth noting that the above list has suggested a series of learning activities, which are essential to help students carry out future exploratory and discovery study of the other environments. These activities thus make up a dimension of variation of the possible ways of exploring the environment. The opening up of such dimension of variation of learning activities is a result of the existing variation in how the students look into the issues, dilemmas and problems teachers raised before the trip, observed by themselves during the trip, and discussed after the trip for presentation purposes. (Runesson \& Marton, 2002)

\section{Variation in the level of the learning tasks and the learning outcomes}

Another variation identified in this field project involved a variation in the level of learning tasks with regard to their intellectual demand and the cognitive level involved. There were altogether three levels of the learning tasks identified in this field project (see Figure 1). In terms of opening up of the dimension of this variation, it focused on varying the level of exploring and understanding the different environments. Students were guided by the task sheet to explore the four environments and their associated issues in a hierarchical manner, that is, from simple to complex, from concrete to abstract, and from surface learning to in-depth learning.

This variation created targets to realise the aim of widening learning space and equip students with those possible strategies for learning and for investigating the different environments. By varying the types of environment, varying the learning activities in group interactions, and varying the levels of investigation and thus the related understanding, students' environmental learning takes place in a more diversified way and such learning is no longer confined to a simple linear pattern. Instead, students are able to see the multiple relationships among the variations.

\section{Major Teaching and Learning Activities as Reflected by the Adopted Educational and Environmental Ideologies of the Field Project}

In this section, ideas about the ideologies of education and environmentalism reviewed by Fien (1993) are used to analyse the teaching and learning activities of the field project. Figure 2 (Fien, 1993: 40) summarises the relation between educational and environmental ideologies to the three teaching approaches to environmental education.

The approaches, intentions and underlying ideologies of environmental education are interwoven to form the focal conceptual framework as described in Figure 2 to reveal the design rationale and the subsequent implementation of the field project. The primary aim of the field project is to achieve the goals of 


\begin{tabular}{|c|c|c|c|}
\hline \multirow{4}{*}{ 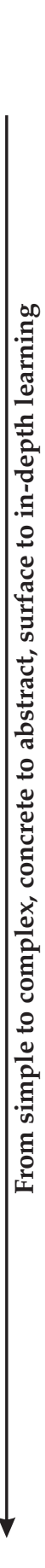 } & & $\begin{array}{l}\text { Level of learning tasks designed to } \\
\text { explore and understand the } \\
\text { environment }\end{array}$ & Examples \\
\hline & Level 1 & $\begin{array}{l}\text { Learning tasks involved lowest } \\
\text { intellectual demand and cognitive } \\
\text { level. } \\
\text { - The tasks require students to } \\
\text { record, observe or sense what are } \\
\text { distinctive to them. } \\
\text { - These tasks are all designed by the } \\
\text { teacher, which represents a high } \\
\text { degree of teacher-led and } \\
\text { teacher-guided learning tasks. } \\
\text { The learning outcomes remain at } \\
\text { the knowledge/ recall level. }\end{array}$ & $\begin{array}{l}\text { - To record the names of } \\
\text { the plants in the school } \\
\text { garden. } \\
\text { - To use human sense } \\
\text { organs to describe a river } \\
\text { in an industrial area - to } \\
\text { smell and to look for } \\
\text { pollutants. }\end{array}$ \\
\hline & Level 2 & $\begin{array}{l}\text { - Learning tasks involved higher } \\
\text { intellectual demand and cognitive } \\
\text { level. } \\
\text { - The tasks require students to } \\
\text { search, gather, filter, process and } \\
\text { organise data collected from the } \\
\text { field sites, Internet and exchange } \\
\text { with their classmates. } \\
\text { - These tasks are all designed and } \\
\text { guided by the teacher but involve } \\
\text { a limited degree of students' own } \\
\text { ideas and interpretation. } \\
\text { - The learning outcomes are } \\
\text { upgraded to the level of compre- } \\
\text { hension, analysis, synthesis and } \\
\text { application }\end{array}$ & $\begin{array}{l}\text { - To conduct discussion } \\
\text { on issues raised by the } \\
\text { teacher as contained in } \\
\text { the task sheet. } \\
\text { - To communicate and } \\
\text { negotiate with group } \\
\text { members to come up } \\
\text { with sensible and logical } \\
\text { results. } \\
\text { - To present the discus- } \\
\text { sion results in class. }\end{array}$ \\
\hline & Level 3 & $\begin{array}{l}\text { - Learning tasks involved the } \\
\text { highest intellectual demand and } \\
\text { cognitive level. } \\
\text { - The 'think-in-depth' tasks engage } \\
\text { students in problem solving. } \\
\text { - The exhibition demands students } \\
\text { to be reflective which requires the } \\
\text { process of value judgement. } \\
\text { - These tasks are the least } \\
\text { teacher-led and involve the } \\
\text { highest level of students' } \\
\text { involvement. } \\
\text { - The learning outcomes are further } \\
\text { upgraded to the level of compre- } \\
\text { hension, analysis, synthesis, } \\
\text { application, evaluation and } \\
\text { judgement. }\end{array}$ & $\begin{array}{l}\text { - To hold a photographic } \\
\text { exhibition to share their } \\
\text { own feelings and } \\
\text { impressions about the } \\
\text { school environments } \\
\text { with other students. }\end{array}$ \\
\hline
\end{tabular}

Figure 1 Variation in the levels of the learning tasks and learning outcomes 


\begin{tabular}{|c|c|c|c|c|}
\hline \multirow{2}{*}{\multicolumn{2}{|c|}{ Environmental ideology }} & \multirow{2}{*}{\multicolumn{3}{|c|}{ Educational ideology }} \\
\hline & & & & \\
\hline \multirow[t]{3}{*}{ Techno-centric } & $\begin{array}{l}\text { Cornucopian } \\
\text { (non-green) }\end{array}$ & $\begin{array}{c}\text { Conservative } \\
\text { education about the } \\
\text { environment }\end{array}$ & 4 & \\
\hline & $\begin{array}{l}\text { Accommodation } \\
\text { Managerialism (light } \\
\text { green) }\end{array}$ & 4 & $\begin{array}{l}\text { Liberal education } \\
\text { about the } \\
\text { environment }\end{array}$ & \\
\hline & $\begin{array}{c}\text { Commualist } \\
\text { Ecosocialism (red } \\
\text { green) }\end{array}$ & & $\begin{array}{l}\text { Liberal education } \\
\text { through the } \\
\text { environment }\end{array}$ & $\begin{array}{l}\text { Critical education } \\
\text { for the environment }\end{array}$ \\
\hline$\downarrow_{\text {Eco-centric }}^{\searrow}$ & $\begin{array}{l}\text { Gaianist Utopian } \\
\text { (dark green) }\end{array}$ & & $\begin{array}{l}\text { Liberal education for } \\
\text { the environment }\end{array}$ & $\rightarrow$ \\
\hline
\end{tabular}

Figure 2 Educational and environmental ideologies in different approaches to environmental education

Source: After Fien, 1993: 40.

Notes: $\rightarrow$ Showing possible ideological directional move to less restrictive definitions and analyses of education about, through and for the environment.

Shaded boxes to show focal emphasis of ideologies intended by the field project.

liberal / progressive education combined with a greater emphasis on environmental ideologies of both 'Accommodationist Managerialism' and 'Communalist Ecosocialism' and perhaps and achieving the 'Gaianist Utopian' as well. Instead of reviewing the meaning of each of the combinations here, the following discussion is carried out using appropriate evidences to justify the adoption or consideration of the above claimed ideologies.

\section{Phase 1: Fieldwork as the major learning activity}

The nature of the activities included in this field project is vital to bring about meaningful geographical and environmental learning among students. There are altogether three main types of learning tasks incorporated in the three phases of this field project. The major learning task carried out in Phase 1 was a piece of fieldwork done in the school ground, and its surroundings. The adoption of fieldwork in this phase is based on the belief that it occupies an irreplaceable status in geographical learning. This use of the school surrounding environment as an authentic medium for education is to reflect a strong flavour of Gaianist ecocentric values as suggested by Fien (1993: 42).

As shown and promoted by many geography educators (Carneiro, 1988; Foskett, 1997; Gerber \& Chuan, 2000; Lai, 1999; Laws, 1989; Lidstone, 1988; Kwan, 2000), fieldwork is undoubtedly a kind of multi-functional learning activity, which is able to deliver different dimensions of learning. By engaging the students in such outdoor learning activities, the learning restriction posed by the four walls of the classroom is overcome and students are provided with immediate contact with their learning environment, that is, their school surroundings (Lidstone, 1988). This approach, as an echo to wide-life learning opportunity outside the school and the widening of students' learning space 
through the use of authentic environment (CDC, 2000b: 29, 53), provides a good opportunity for students to learn in an 'open' manner (Fien, 1993: 22). All these are essentially the basic characteristics of liberal/ progressive education. Although this field project is not of a field research-oriented nature and is still very much teacher-led in the sense that fully prescribed task sheets are provided, the adoption of 'issue-based inquiry' learning approach is clearly there (Foskett, 1997). This reflects also the element of liberal / progressive education orientation (Fien, 1993: 22). Even more so is the engagement of the students to learn through initial observations that can cultivate their learning curiosity and awareness (Lidstone, 1988). This indeed is what a 'child-centred' (Fien, 1993: 42) curriculum means in Gaianist ecocentric environmentalism.

\section{Phase 2: Class discussion and role play as extended learning activities}

In Phase 2 of the field project, students were required to go through several extended learning activities. After obtaining primary data from the actual field study in Phase 1 and additional data collected from the Internet, students were then engaged in group discussion and role playing. The rationale of having these activities to bring about meaningful learning has been discussed widely and is very much welcomed and recommended in the 'liberal education about the environment' and 'involving elements of dark green and red-green environmentalism' (Fien, 1993: 41). The reason is that students engaging in these activities are given plenty of opportunities to express their views and to reflect the effects of their lifestyles, which may contribute to any environmental problems (Fien, 1993). Bruce et al. (2004) appraise group investigation and believe that through discussion students can learn from each other to increase their ability to work together, develop positive feelings towards one another, build relationships, provide affirmative views of other people and eventually increase self-esteem. In addition, interacting with one another produces cognitive as well as social complexity, which creates more intellectual activity and as a result enhances learning.

What is important to clarify here is that role play and group discussion are not new to most students of this group, or indeed to other classrooms in Hong Kong. However, the Hong Kong local experience tells us that these activities usually appear to be a 'separated' learning task and not part of the normal classroom routine. Often, they are seen as substitute for teacher exposition. Though teachers may not have these intentions, students may share similar feelings and not feel like participating actively in such learning activities and thus lower their learning motivation. This may be due to the fact that teachers have usually assumed the direction for discussion or role playing in advance and do not really encourage initiation and active participation by the students. Besides, the problem situation or scenario that is set in the role play or discussion is often detached from the students' own familiar cultural background and learning experiences and so do not promote interest or stimulate learning motivation. As suggested by Bruce et al. (2004) and Stimpson and Tao (1994), making use of the familiar and authentic environment is essential to the conduct of any successful and effective group discussion or role playing in the classroom. Fien (1993) also made the point clear that 'liberal / progressive educational and Gaianist environmental ideologies in education through the environment is best provided 
through child-centred (learner-centred) activities as brought about in the authentic environment' (p. 42). When students are not provided with a stimulating or appropriate learning context, they certainly are not eager to join in. In this field project, instead, students are effectively motivated and participated in the discussion and role playing actively. This is because the students themselves have identified some of the issues involved when conducting the field study of the four sites of different environments. This 'sense of belonging' or 'ownership' to those issues and problem situations can intensify students' incentive to explore further. They now see a real 'need' to solve the issues and no longer regard those activities as separated and unrelated learning tasks.

\section{Phase 3: Photograph exhibition for reflection}

In the third phase of the field project, students were required to display the photographs they had taken in the field to express their feelings towards the surroundings to other children. This photograph exhibition serves two main functions. First, to give students themselves a valuable opportunity to reflect using a non-verbal means after they have experienced the four different environments. Second, to use those photographs to share and communicate their inner feelings with other students and to convey the message of environmental responsibility. To become a reflective learner, students are required to express and to evaluate their own feelings, attitudes and behaviours in order to make judgements with self-confidence. Also, the use of non-verbal photograph communication implies that students are indeed doing something for the environment as this involves the 'development of moral awareness' (from reflection) and their 'commitment' to take some meaningful action to protect the environment (Fien, 1993: 43). Other students who share similar feelings as expressed by the photographs may at least reflect on their current behaviour and think about what other possible action can be taken to contribute to environmental protection. This can be regarded as the first but a vital step to take action to improve the sustained quality of the environment.

The overall activities of this field project include group inquiry fieldwork, class discussion, role-play exercises and the photograph exhibition. Again, they are by no means new practices to most schools and students in Hong Kong. However, as a school-based curriculum field project, it is well orchestrated by the teacher at the planning and designing stage to ensure the opening up of the learning space of the students. This is then followed by the inclusion of well constructed self-directed questions / tasks to allow students to embark on their field inquiry or investigation as a group with the liberal/progressive educational ideologies and the ecocentric environmental ideologies in mind to bring education through and for the environment. This has certainly made this field project different from the other conventional field projects. Also, its strong skill and attitude orientation represents a rather big step forward for the school, teachers and students, to move towards a more learner-focused geographical and environmental curriculum. The worth of conducting this field project lies in its emphasis on the learning processes, not directly on the outcomes. This indeed has a valuable and influential implication to the school to improve its future curriculum. 


\section{What Kind of Intended Learning Outcomes were Planned for the Students?}

Though the emphasis up to now has been on the learning processes, this last part of the paper focuses on addressing the intended learning outcomes planned by the designers, based on the various activities in this field project as described above. The overall intended learning outcomes of this field project are to advocate meaningful environmental and geographical issues bearing the liberal/ progressive educational ideology. This, in particular, will highlight the ecocentric environmental ideology as discussed above, with the purpose of illustrating how the learning space of the students could have been opened up. However, one should note that there may be slippage in the actual delivery of the field project leading to some unintended as well as the intended learning outcomes. But the focus of this part is to share with the readers the intended learning outcomes based on the design of this issue-based inquiry field project with respect to knowledge, skills, values and attitudes.

\section{Knowledge to be learned}

Knowledge, represented as concepts, ideas and facts, forms the focus that we want our students to learn and to make sense of the world. Knowledge should not be solely learnt from teacher's direct exposition inside the classroom. Instead, knowledge should be constructed, generated and initiated by students themselves with the teacher's guidance through engaging in various well-planned learning activities and learning environments (CDC, 2000b: 51). By doing so, students can make use of what they have learnt now to help with their future learning and investigation. Indeed, the geographical and environmental knowledge that we intend the students to learn forms the invariance of the field project. Students' learning space, however, is opened up through the variation of different environments (namely, the school, urban, industrial and rural) and the different learning activities to produce different learning experiences. Also, as a kind of environmental education, the knowledge objectives involved should best 'help students gain a variety of experiences within the total environment and develop a basic understanding of the total environment, its associated problems, and humanity's critically responsible presence and role in it' (Fien, 1991: 15).

In respect to the promotion of self-knowledge construction, this field project offers an opportunity for students to construct their own meaning of some abstract and difficult but important concepts in studying geography and the environment. For instance, the concepts of 'location', 'distribution', 'association', 'interaction' or 'change' are commonly found in every geographical and environmental topic. Though students can 'reproduce' them in the written tests or examinations, rarely can they account for the implications and meanings of these concepts clearly and precisely. These concepts still remain as a kind of woolly, prescriptive, factual, abstract, absolute propositional geographical knowledge. Students learn as passive recipients. To break away from this traditional way of knowledge teaching, this field project helps those abstract concepts to come alive in students' minds (Laws, 1989) through engaging in 'a great variety of learning experiences within the different authentic environment' (Fien, 1991: 15). In other 
words, while the students were asked to judge the worthiness of constructing the West Rail in the northwestern part of the New Territories in Hong Kong, they have to explore the location and distribution of this railway network and to associate the benefits/shortcomings brought by the intensified interaction between the human encroached urban development and the sacrifice of the rare natural rural environment. Also, the students have to compare the data they obtained from the field sites with those of historical maps to check out the change of land use, in particular the diminishing proportion of rural land use. Instead of being told by the teacher, students are 'encouraged' to explore and identify themselves through genuine participation and thus gain real experiences. The knowledge they construct, unlike the propositional knowledge, involves a higher cognitive level because students need to organise, interpret, relate and anticipate data they gather and events they come across in the field (Hall, 1989). They will then know how, when, where and why to use those concepts in future. This is what we usually refer to as procedural and contextual knowledge (Gilbert \& Vick, 1996). The concepts learned represent both the process and also the end product of the learning activities which should be much more meaningful and useful to help students' future geographical and environmental learning and investigation.

Using Hall's (1989) approaches to knowledge, the approach this field project adopted is very much inclined to the humanism type of knowledge, that is, what he calls affective knowledge. This kind of knowledge is critical as it helps to illuminate humans' role and responsibility in many environmental issues, which is knowledge encouraged by successful environmental education (Fien, 1991). The role-play activity and the decision-making task in Phase 2 activated students' empathy feelings towards their surroundings and involvement in perfecting their school garden. Also, during the discussion session, critical and personal appreciation of the decision-making process is successfully promoted among students. In such a context, the study of rights and responsibilities of individuals and of social groups and the analysis of the interdependence of people, places and environment (e.g. to decide how to protect the river from pollution, to conserve the rural beauty from urban encroachment) are as significant as the understanding of skills, concepts and facts (Hall, 1989).

\section{Skills to be acquired}

Undoubtedly, skill learning is also of significant importance to students because skills provide the means whereby learning takes place. According to Fien (1991), the development of environmental education related skill aims to help students to identify, investigate and solve environmental problems (p. 15). In addition to what has been suggested about knowledge learned, this field project also involves a greater range and variety of generic skills development to fulfil the aims of the current Hong Kong educational reform (CDC, 2000a). However, such skill acquisition cannot be learned as a stand-alone practice or discrete part of the field project, but has to take place in association with knowledge, processes and values learning.

To begin with, skills related to information acquisition and collection, involving observation, recording, and clarifying features of the environment according to their aesthetic qualities, are acquired through going outside to look for data in the four field sites. For the study and numeracy skills, collecting 
information from the Internet, discussing issues and sharing with group members are all critical skills to be nurtured in those extended activities as contained in the second and third phase of the field project. As suggested in the previous section, participation in discussion allows students to learn to be open-minded and responsive to others' ideas. They also have to appreciate, encourage and support the ideas and efforts contributed by their peers. These are all crucial to develop their collaboration skills. For instance, in the extended activity designed for the school garden environment, the students had to decide whether they chose to build the new multipurpose teaching complex or to retain the paper-bark trees (Melaleuca) in the school garden. They have to listen and read, to use effective and appropriate means of communication to inform, persuade and argue with fellow group members to arrive at a desirable outcome. On top of that, students have been given plenty of opportunities to practise their creativity (e.g. to design an effective device to protect the deteriorating paper-bark trees which is a symbolic representation in the school garden), critical thinking skills (e.g. to judge whether West Rail is really environmentally friendly and an economic necessity by investigating and comparing the claims made and observed from reality), problem-solving skills (e.g. to suggest effective ways to eliminate pollution problems along Shan Pui River flowing alongside the industrial estate of Yuen Long new town) and self-management skills (e.g. to evaluate and express their feelings in a confident way by posting up their photographs taken from the sites to spread the message of environmental concerns and protection to other fellow students). As one can see, this field project is valuable in helping students to cultivate the learning of a number of generic skills, which can ultimately prepare them to learn how to learn geographically and, more importantly, to be equipped appropriately to investigate the other environmental concerns in greater depth in the future.

\section{Values and attitudes to be cultivated and nurtured}

As mentioned in the key learning area of personal, social and humanities education document (CDC, 2000b), though there have been many value-oriented cross-curricular guidelines, such as environmental education issued before (CDC, 1999), values education is not as successfully developed in students as the knowledge components in Hong Kong (CDC, 2000b: 37). This implies that greater attention should be given to the enhancement of values and proper attitudes in any future curriculum planning. Fien (1991: 16) stressed that a geography curriculum that only teaches about the environment will be 'little more than "water off a duck's back" unless students are provided with opportunities to explore alternative environmental values and to develop appreciation and concern for ecological sustainability and human beings'. This accords perfectly with Wiegand (1986: 53) who stated 'geography is concerned with the interrelationship between people and places'. With that, values exist in geography through human decisions and sense of belonging to the place. So, the fieldwork and other learning tasks in this field project allow values education to be injected by engaging students to understand better the interrelationship between the observed landscape around the school and the possible reasons behind it. In addition, the cultivation of commitment, responsibility and 
sustainability, being the three key values in environmental and geographical education, are much stressed in this field project.

The activities designed reveal the intention as well as the function of strengthening students' values with respect to environmental concerns, individual and social responsibility for their immediate surroundings. For instance, to inquire into foreseen and unforeseen consequences of human actions and decisions in landscape development, such as pollution (around the industrial buildings along Shan Pui River), massive replacement of natural rural landscape with built-up areas (the further development of a new town), helps students to understand better the meaning of sustainability (Arnold, 1985). Besides, as members of the school, students were asked to develop a useful device to protect the paper-bark trees (Melaleuca) in the school garden. This is an effective way of helping students to develop their sense of commitment and responsibility to protect their school properties. Once they were given a chance to set up the device in the school garden, the sense of belonging automatically drove them to bear the responsibility to keep the proper management of the device and thus helped to continue the sustained protection of the 'vandalised' trees in the school garden.

Undoubtedly, the achievement in value development brought about by these activities could possibly be short term because values and attitudes education demands a long time to have the effects penetrate to form habitual behaviour amongst students. So, this field project serves as one of the catalysts only. It is necessary for teachers to uphold similar learning activities with an emphasis of learning variation to sustain meaningful learning as intended by this field project.

\section{Conclusion}

This paper serves the purpose of describing and analysing how the design of a school-based environmental field project has brought about meaningful learning to students according to the expectations of the current educational reform in Hong Kong. Using the Marton and Booth (1997) theory of learning and awareness and Fien's (1993) educational and environmental ideologies as a conceptual framework, the authors have undertaken a genuine reflection to critically comment on the field project design and justify the intended learning outcomes of the field project. From the above illustration and analysis, this field project appears to be a good trial for both students and teachers to gear up towards the ideal teaching and learning situation to achieve both meaningful and effective geographical and environmental education. However, it has to be admitted that some of the learning tasks designed may not be strong and adequate enough to provide students with very sophisticated learning experiences that can develop a very high level of 'socially critical' understanding, skills and values in environmental education. For example, one may still consider the fieldwork to be very much teacher led with not enough opportunity given to students to conduct their own investigation purely based on their interests, and so the liberal / progressive flavour might be regarded as inadequate with room for further improvement. Undoubtedly, the lack of readiness of students towards a genuine studentfocused learning can be a major barrier for such design. Nonetheless, the 
discovery and inquiry approaches to bringing about geographical and environmental knowledge learning, skills practising, and values and attitudes construction are very much moving towards the learner-focused planning of the curriculum. The opening of the students' learning space by the provision of different variations has created opportunities to bring about a higher level of learning among students. In this sense, the students are no longer passive learners but learning to become active empowered small environmentalists in their own right.

\section{Correspondence}

Any correspondence should be directed to Tammy Kwan, Faculty of Education, The University of Hong Kong, Pokfulam Road, Hong Kong (tylkwan@ hkucc.hku.hk).

\section{References}

Arnold, J. (1985) A Problem Solving Approach to Environmental Education. Environmental Education Series 15. Division of Science, Technical and Environmental Education, UNESCO.

Bruce, J., Weil, M. and Calholin, E. (2004) Models of Teaching (7th edn). Singapore: Allyn and Bacon.

Carneiro, S.M. (1988) Objectives for field work and laboratory studies in geography at primary and secondary school. In R. Gerber \& G.K. Chuan (eds) Fieldwork in Geography: Reflections, Perspectives and Actions. Boston, MA: Kluwer Academic.

Curriculum Development Council (CDC) (1999) Guidelines on Environmental Education in Schools. Hong Kong: Education Department.

Curriculum Development Council (CDC) (2000a) Learning to Learn: The Way Forward in Curriculum Development. Consultation Document. HKSAR: Curriculum Development Council.

Curriculum Development Council (CDC) (2000b) Learning to Learn: Key Learning Area: Personal, Social \& Humanities Education. Consultation Document. HKSAR: Curriculum Development Council.

Fien, J. (1991) Geography's contribution to environmental education. Geographical Education 6 (3), 14-18.

Fien, J. (1993) Education for the Environment: Critical Curriculum Theorizing and Environmental Education. Deakin-Griffith Environmental Education Project. Geelong: Deakin University Press.

Fien, J., Cox, B. and Fossey, W. (1989) Geography: A medium for education. In J. Fien, R.Gerber and P. Wilson (eds) The Geography Teacher's Guide to the Classroom (2nd edn). Brisbane: Macmillan.

Foskett, N. (1997) Teaching and learning through fieldwork. In D. Tilbury and M. Williams (eds) Teaching and Learning Geography. London: Routledge.

Gerber, R. and Chuan, G.K. (2000) The power of fieldwork. In R. Gerber and G.K. Chuan (eds) Fieldwork in Geography: Reflections, Perspectives and Actions. Boston, MA: Kluwer Academic.

Gilbert, R. and Vick, M. (1996) The knowledge base for study society and environment. In R. Gilbert (ed.) Studying Society and Environment: A Handbook for Teachers. Melbourne: MacMillan.

Hall, D. (1989) Knowledge and teaching styles in the geography classroom. In J. Fien, R. Gerber and P. Wilson (eds) The Geography Teacher's Guide to the Classroom. Brisbane: Macmillan.

Kwan, T. (1995) Preparing 'small' environmentalists through activity-based and interdisciplinary environmental teaching. New Horizon in Teaching 36 (November), 94-103. 
Kwan, T. (2000) Fieldwork in geography teaching: The case in Hong Kong. In R. Gerber and G.K. Chuan (eds) Fieldwork in Geography: Reflections, Perspectives and Actions. Boston, MA: Kluwer Academic.

Lai, K.C. (1999) Freedom to learn: A study of the experiences of secondary school teachers and students in a geography field trip. International Research in Geographical and Environmental Education 8 (3), 239-55.

Laws, K. (1989) Learning geography through fieldwork. In J. Fien, R. Gerber and P. Wilson (eds) The Geography Teacher's Guide to the Classroom. Brisbane: Macmillan.

Lidstone, J. (1988) Teaching and learning geography through field work. In R. Gerber and J. Lidstone (eds) Developing Skills in Geographical Education. Brisbane: Jacaranda.

Marton, F. and Booth S. (1997) Learning and Awareness. NJ: Lawrence Erlbaum.

Marton, F., Runesson, U. and Tsui, A.B.M. (2004) The space of learning. In F. Marton and A.B.M. Tsui (eds) Classroom Discourse and the Space of Learning. NJ: Lawrence Erlbaum.

Ramsden, P. (1988) Study learning: Improving teaching. In P. Ramsden (ed.) Improving Learning: New Perspectives. London: Kogan Page.

Runesson, U. and Marton, F. (2002) The object of learning and the space of variation. In F. Marton and P. Morris (eds) What Matters? Discovering Critical Conditions of Classroom Learning. Göteborg, Sweden: ACTA Universitatis Gothogurgensis.

Stimpson, P. and Tao, P.K. (1994) Issues-based Teaching. Hong Kong: Longman.

Wiegand, P. (1986) Values in geographical education. In P. Tomlinson and M. Quinton (eds) Values Across the Curriculum. Barcombe: Falmer. 


\section{Appendix: The Full Description of the School-based Environmental Field Project}

WHAT HAPPENS AROUND YOU AND YOUR SCHOOL AREA?

Am I a 'super student' who knows everything around the school?

To test yourself, try to answer the following questions:

(a) Can you name at least four plants that you can find in our school garden?

(b) Do you notice we have a 'big' construction site over the open ditch just outside the main gate of our school? What is under construction there?

(c) Do you know why you always have to 'hold your breath' when you walk your way back home along Wang Lok Street?

(d) Are you aware that we are still able to find small patches of farmland close to our school? Where are they? Will they stay long?

If you have no idea to the questions above, don't worry! Come and join the walking of a trail near our school to find out the answers!

Instruction to Students: What to Do During the Trail?

This trail exercise includes two main parts:

(a) Four on-site tasks - search for answers while you walk along the trail.

(b) Follow-up activities - questions to be considered further after the trail walk.

The four main themes of this trail exercise are:

1. Do you enjoy your school garden?

- To find out how much you know about our school garden.

2. Do you welcome the construction of the West Rail?

- To examine whether urban development and environment preservation can coexist through the issue inquiry of the West Rail construction.

3. Do you like the factories where they stand now?

- To determine whether it is acceptable to prosper our economy but destroy our lovely environment.

4. Should we value the 'Rural Beauty'?

- To treasure and preserve our limited and valuable rural beauty in Yuen Long Town.

You are expected to complete the questions in each theme while walking along the trail. The 'Think in Depth' will be discussed in the subsequent debriefing section.

A role-play activity will be carried out in the discussion section. Pay attention to the role assigned to your group.

Read through the worksheet before you start walking the trail. 


\section{\$ Grouping}

- Form yourself into groups of 4-5.

- Elect one member to be your group leader and another be the camera person.

\& What do I have to take with me?

When you do the trail walk, you should take with you:

- A set of worksheet.

- Two base maps - 1:4000 (Map of Long Ping Estate) and 1:10,000 (Map of Yuen Long Town)

- A compass

- A clip board for each group

- A camera (if you are the camera person)

- Two blank sheets for drawing sketches.

s Do I need to follow the sites along the trail?

- You are advised to go from Site 1 to 4 in sequence. Otherwise, you may have some problems in finding out the answers for the tasks.

Besides the tasks listed, what else do I do?

- You need to take photographs as evidence to support your group's impression.

- Among the photographs you've taken, select ONE to show the Best scene and ONE to show the Worst scene along the trail. Suggest reasons and objectives for taking these two photographs.

- Your photographs will be exhibited in the school display bulletin board later.

ـ Time needed to complete the on-site task

- You need about $2 \frac{1}{2}$ hours. 


\section{Theme One (refer to Site 1 on Map 1): Do you enjoy your school garden?}

1. Where do you think the photograph shown below was taken from?

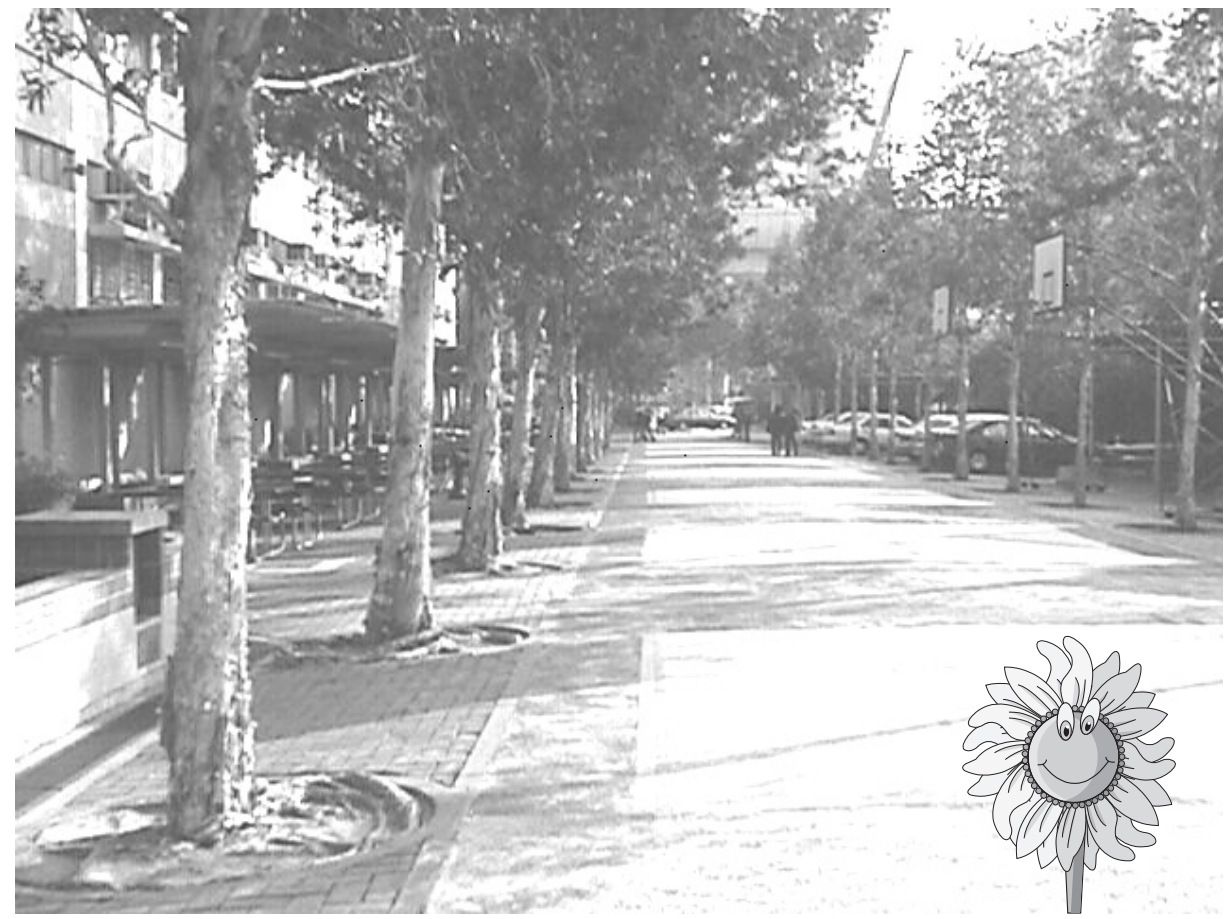

2. (a) Can you give as many names of the plants as possible in our school garden?

(a)

(d)

(g)

(j) (b)

(e)

(h)

(k) (c)

(1)

(b) Which plant do you like the most? Why?

3. (a) Pay particular attention to the trees in the photograph. They are the most 'welcome' species in our school. Do you know what it is and why it is the most 'welcome' species?

(Hint: Look at the tree barks. Any difference in bark appearance between the middle and the upper part of the tree? Who causes such a difference?)

(b) What do you think about the damaging action done by your fellow schoolmates?

(c) Now our Principal hopes that we can do something to protect the tree barks from further vandalism. Can you design a device that can be used to avoid further damaging? Draw it in the space below.

(Note: you are also responsible for making the device. So, your design should 
be simple and of course be practical. And your design should not destroy very much the beauty and natural growing of the trees!)

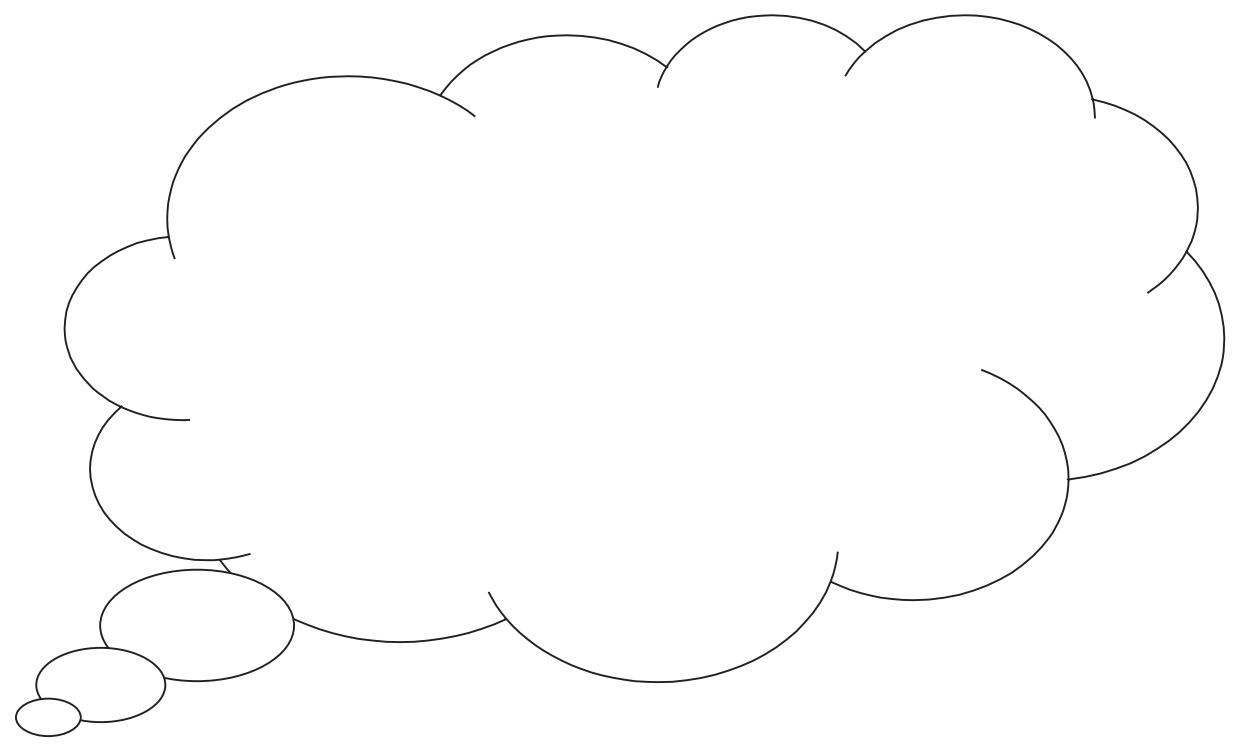

(d) Instead of 'designing a good device' to protect the tree, what else do you think can really help to protect the trees from further vandalism?

Think in depth

Suppose we now get one million dollars from the School Management Board of Directors to improve our school facilities. Our school management board would like to construct a new building to include an IT Room, a Student Union Activity Room and a Study Room for our students. The only piece of land available for these new additions of facilities is the school garden. Will you support the plan? Why?

- Be prepared to give your view when we have the debriefing section in school.

\section{Theme Two (refer to Site 2 on Map 1): Do you welcome the construction of the West Rail?}

-Attention please:

- Beware of the vehicles when you have to cross the roads.

- Do not walk into the construction site without permission because it can be dangerous.

- Take photographs whenever necessary.

1. After you leave the school main gate, walk southward to Ping Yee Road. Do you notice a construction site over the open ditch? What is under construction now?

2. Can you list as many benefits as possible the new service you have identified will bring to Yuen Long new town in the future? Do you like them? Why? 
3. Walk along Ping Yee Road. Can you tell what is going on in the construction site? For example, how many machines are there? What are the machines used for? Do you find any destruction of existing structure in the site?

4. Suppose you are a resident in Yuet Ping House and Ho Ping House. What problems do you encounter during the construction period? What problems may you expect after the completion of the West Rail while it offers the wonderful transport service to the public?

5. While you may feel lucky not being the residents of these two buildings, do you still regard the construction of West Rail a benefit to the public and the environment? Why?

Think in depth

Read the following two extracts and consider the questions below:

Extract 1 Information about the West Rail

\begin{tabular}{||l|c||}
\hline Alignment length & $30.3 \mathrm{~km}$ \\
\hline Number of stations & Nine \\
\hline Train speed & Max: $130 \mathrm{~km} /$ hour and average: $60 \mathrm{~km} /$ hour \\
\hline Journey time & 30 mins from Tuen Mun Centre to Yen Chow Street \\
\hline Max. Passengers / car & 335 passengers \\
\hline Average daily patronage forecast & About 340,000 in year 2003 \\
\hline
\end{tabular}

\section{Extract 2}

West Rail is claimed to be an environmentally friendly project:

(1) As an electrified railway, West Rail will help reduce air pollution by eliminating the need for the equivalent of 2500 bus trips per day, thus significantly reducing vehicle exhaust emissions.

(2) Use of noise absorptive lining, noise barrier and rubber pads (for supporting track slab) make West Rail one of the quietest railways in the world.

(3) Large portion (about $16.5 \mathrm{~km}$; more than half of the total length) of the rail in Yuen Long and Tuen Mun will be constructed over elevated viaduct to avoid damage to underground and maintain good drainage.

(4) The provision of $\mathbf{1 2}$ hectares of wetlands to replace habitats assimilated by West Rail Phase I.

Source: http: / / www.kcrc.com/eng/service/wreb.html

(a) To what extent do you think West Rail is an efficient and effective transportation means in the coming decade for the northwestern part of the New Territories?

(b) Do you think the Kowloon-Canton Railway Company (KCRC) has done enough work to 'compensate' for their destruction to the environment? Why? 
(c) Comment on the whole project based on the two principles listed below.

- 'The right to development must respect the development and environmental needs of present and future generations' (Agenda 21, 1992)

- 'To achieve sustainable development environmental protection shall be an integral part of the development process' (Agenda 21, 1992)

\section{Theme Three (Refer to Site 3 on Map 1): Do you like the factories where they stand now?}

* Attention please

- Beware of the vehicles when you have to cross the roads.

- Do not walk into the construction site without permission because it can be dangerous.

- Take photographs whenever necessary.

1. When you get to the junction of Ping Yee Road and Wang Lok Street, do you smell anything? Do you like the smell? How would you describe the smell? Where do you think the smell comes from? Why?

2. Cross Wang Lok Street and then walk along the 'riverside'.

Look over to the other side of the river, what are the buildings used for?

3. Draw a sketch of the surrounding area.

4. What are the differences between now and the past?

(a) Can you point out the differences between this Shan Pui River and a natural river? Have you heard from your parents about the original appearance of Shan Pui river?

(b) What are the uses of having large outlets of the drains along Shan Pui River?

(c) Why do you think Shan Pui River is changed to take the shape and look of its present state?

5. How do you describe the water in Shan Pui River? Can you offer some explanations to your description?

(a) What is the colour of the water?

(b) Any rubbish flowing in the water?

(c) Can you look through to the bottom of the river?

(d) Any fish or other living organisms that you can find?

(e) Do you think it is a 'healthy' river? Why?

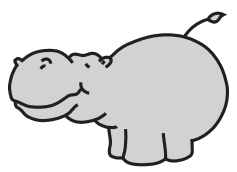

6. As recalled from your memory, does Shan Pui River always get drained by water properly? If no, when the river is dry, what can you find on the riverbed? Where do these substances come from?

Think in depth

(a) To what extent do you think the factories nearby should be responsible for the 'poor quality' of Shan Pui River?

(b) 'he only way to eliminate the pollution problems here is to move away all the factories.' How far do you agree? Why? 


\section{Theme Four (refer to Site 4 on Map 1): Should we value the rural beauty?}

* Attention please

- You need to go upstairs in either Kam Ping House or Sau Ping House for a vantage view and subsequently walk across into Wang Chau.

- All the group members should go together to ensure safety.

1. Walk along Fuk Hi Street and stop at the junction of Long Ping Road. This time you need to go upstairs first to obtain an elevated view of the surroundings. You can go into either Sau Ping House or Kam Ping House to about 25th floor. Find a balcony where you can see both Wang Chau and the low residential density to the north of Long Ping Estate.

2. Draw a sketch of what you can see now from the vantage point. Indicate clearly the orientation of your sketch.

3. After completing the sketch, go back to the ground level and find a way into Wang Chau. You need not go very far. Stop where you can find the farmland. Mark your route on the base map.

4. Can you make a comparison between the scenery here and what you've just seen in Sites 2 and 3 in terms of:

(a) the land use types;

(b) the building density, building height, and their appearances;

(c) the proportion of green area;

(d) your sense impression - look far, take a deep breath and hear ...Which site do you like the most? Why?

5. Do you know what is the original land use of Long Ping Estate? Compare what you have observed with the old map provided by the teacher.

Think in depth

Suppose our Government is planning to develop another housing estate next to Long Ping Estate to offer houses for the increasing population. The best choice is to develop westward, i.e. into Wang Chau. Since it will be a new planned housing estate, special attention will be put on the provision of green and recreational facilities for the future residents. But of course, the existing rural area will inevitably be removed. Will you support the plan? Why? 


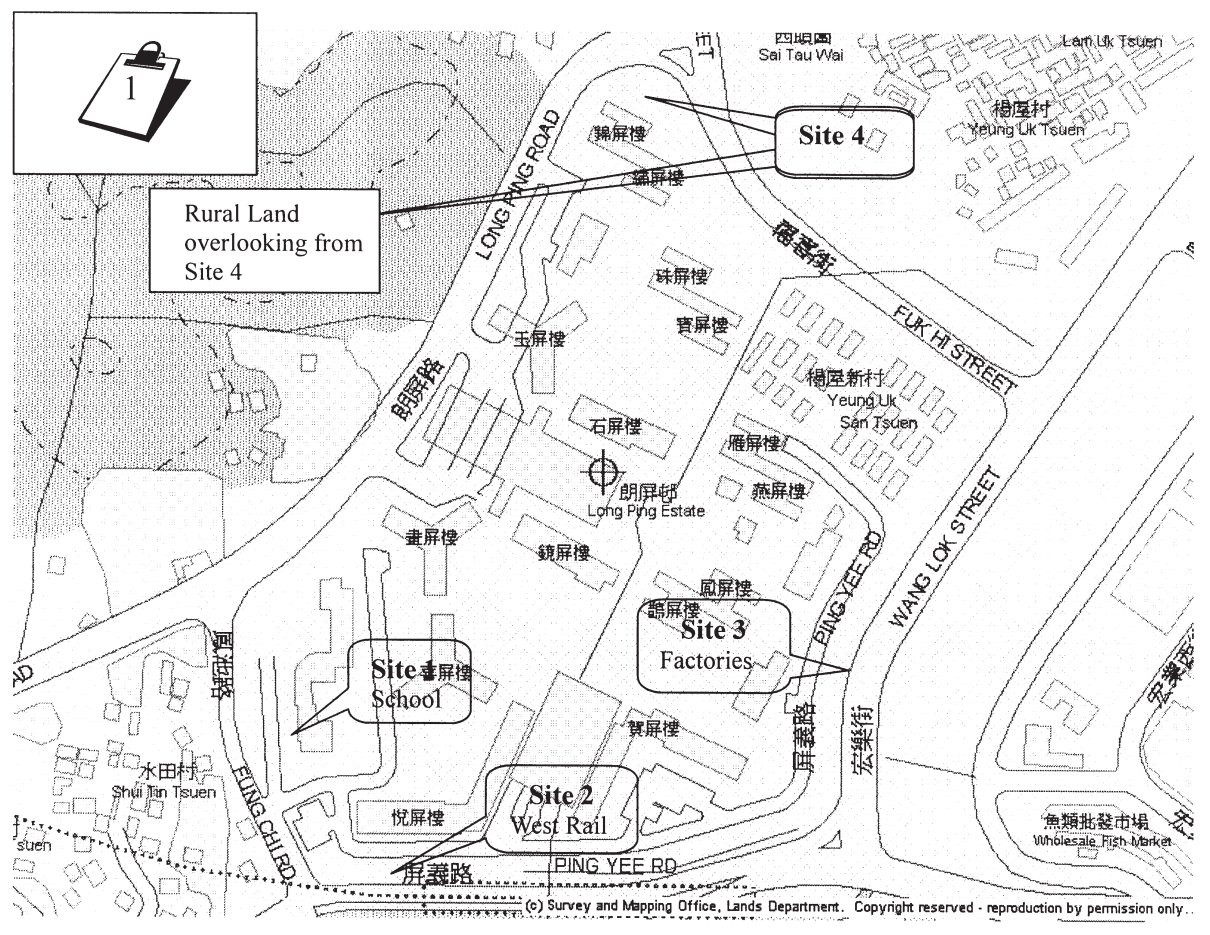

$1: 4000$

N

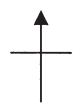

Map 1 Map of the trail walk of the field project 


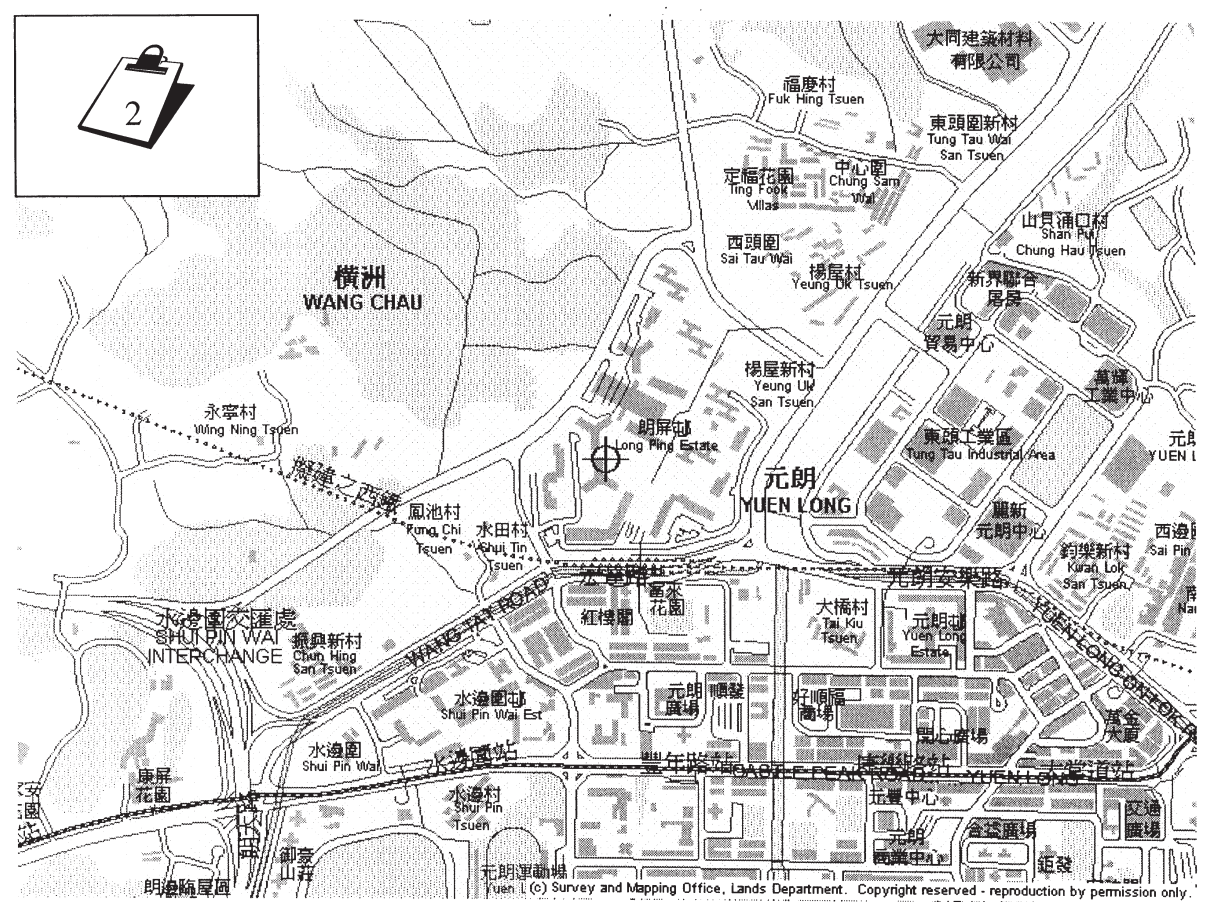

1: 10,000

$\mathrm{N}$

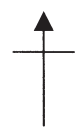

Map 2 Map of Yuen Long New Town 